\title{
PENGARUH CARA DAN LAMA PEMERAMAN TERHADAP KANDUNGAN VITAMIN C PADA BUAH PISANG RAJA (Musa paradisiaca L).
}

\author{
Sri Utami, Joko Widiyanto, Kristianita \\ Program Studi Pendidikan Biologi IKIP PGRI Madiun
}

\begin{abstract}
ABSTRAK
Tujuan penelitian ini adalah untuk mengetahui (1) Pengaruh cara pemeraman yang berbeda terhadap kandungan vitamin $\mathrm{C}$ buah pisang Raja (2) Pengaruh lama pemeraman terhadap kandungan vitamin $\mathrm{C}$ buah pisang Raja (3) Adanya interaksi antara cara dan lama pemeraman terhadap kandungan vitamin $\mathrm{C}$ buah pisang Raja. Penelitian ini dilaksanakan di Laboratorium Biologi IKIP PGRI Madiun pada bulan Juni sampai September 2012. Rancangan penelitian menggunakan Rancangan Acak Lengkap (RAL) dengan 2 faktorial yaitu cara pemeraman dan lama pemeraman. Cara pemeraman dibedakan menjadi daun Lamtoro (C1), Karbid (C2) dan Larutan Ethrel (C3), dan faktor lama pemeraman meliputi 0 hari (L0), 2 hari (L1), 4 hari (L2), 6 hari (L3), dan 8 hari (L4). Data penelitian ini dianalisis dengan menggunakan analisis variansi (ANAVA) ganda. Jika dalam penelitian ini didapatkan nilai $\mathrm{F}$ hitung > Ftabel berarti hipotesis diterima dan untuk mengetahui perbedaan tiap perlakuan dilanjutkan dengan uji Beda Nyata Terkecil (BNT) dengan taraf signifikansi 5\%. Hasil penelitian menunjukkan bahwa: (1) Cara pemeraman yang berbeda berpengaruh terhadap kandungan vitamin $\mathrm{C}$ buah pisang raja (Musa paradisiaca $\mathrm{L}$ ). Pemeraman dengan ethrel menghasilkan rata-rata vitamin $\mathrm{C}$ yang paling tinggi yaitu $8,51 \mathrm{mg}$ setiap 100mg larutan pisang. (2). Lama pemeraman berpengaruh terhadap kandungan vitamin C pada buah pisang raja (Musa paradisiaca $\mathrm{L}$ ). Pemeraman pada hari ke-4 menghasilkan vitamin $\mathrm{C}$ paling tinggi untuk semua perlakuan yaitu $11,02 \mathrm{mg} / 100 \mathrm{mg}$. (3). Ada interaksi antara cara dan lama pemeraman terhadap kandungan vitamin $\mathrm{C}$ buah pisang raja (Musa paradisiaca $\mathrm{L}$ ). Pada cara pemeraman dengan ethrel dan lama pemeraman 2 hari didapatkan kandungan vitamin $\mathrm{C}$ yang paling tinggi dan berbeda nyata dengan perlakuan yang lain.
\end{abstract}

Kata Kunci: Cara Pemeraman, Lama Pemeraman, Vitamin C, Buah Pisang Raja.

\section{PENDAHULUAN}

Pisang raja (Musa paradisiaca L) merupakan salah satu kultivar pisang yang terkenal baik di kota maupun di desa. Selain untuk buah yang dimakan langsung secara segar, pisang raja (Musa paradisiaca $\mathrm{L}$ ) juga banyak digunakan untuk bahan utama berbagai makanan olahan pisang misalnya pisang goreng, keripik pisang dan sale pisang. Pisang raja juga sering disebut pisang meja karena sering diletakkan di meja sebagai buah pencuci mulut yang dikonsumsi dalam bentuk buah segar setelah masak di pohon ataupun melalui proses pemeraman (Rukmana, 1999).

Buah pisang yang terbaik adalah yang mengalami proses pemasakan ketika masih berada di pohon. Namun jika di pasar mungkin sulit untuk mendapatkan buah pisang dengan kualitas tersebut karena para petani penjual pisang tidak akan menunggu buah pisangnya hingga masak dipohon karena nanti bisa jadi pisangnya membusuk sebelum laku dijual di pasar (Mulyani, 2005). Meskipun demikian masyarakat tetap menyukai buah pisang raja walaupun tidak masak pohon dan sudah melewati proses pemeraman. Proses pemeraman diperlukan untuk mendapatkan buah pisang raja yang matangnya secara serempak dengan warna yang menarik.

Ada beberapa teknik pemeraman yang biasa dilakukan oleh masyarakat yakni dengan cara dimasukkan kedalam tempayan. Pemeraman dengan cara ini memakan waktu 2-3 hari. Cara pemeraman lain yaitu dengan 
menggunakan dedaunan. Beberapa jenis daun yang dapat merangsang pematangan buah adalah daun lamtoro, daun gamal, daun mindi dan daun pisang. Pemeraman dengan teknik ini memerlukan waktu 3- 4 hari untuk mendapatkan kematangan buah yang serempak (Zuhairini, 1997: 60). Cara pemeraman tradisional lainnya dengan cara pengasapan, pematangan dengan cara ini dilakukan dengan menempatkan buah pisang di dalam tanah yang sudah digali dan dialasi dengan daun pisang kemudian pisang- pisang tersebut ditutup dengan gedebok pisang dan tanah. Untuk menyalurkan asap digunakan bambu, dan proses pengasapan dilakukan selama 36- 72 jam kemudian lubang ditutup rapat dengan tanah selama 4-5 hari agar buah pisang matang secara seragam (Hukum, 1993: 33). Selain teknik pemeraman secara tradisional para petani juga sering menggunakan gas etilen untuk memeram buah pisangnya yang ternyata hasilnya lebih baik dibandingkan dengan menggunakan karbid. Pemeraman dengan gas ini paling efektif bila buah yang diperam mengandung enzim oksidase karena gas berfungsi sebagai koenzim (Suyanti, 2008:92). Pada umumnya masyarakat menggunakan cara pemeraman dengan menggunakan karbid. Karbid atau kalsium karbida adalah senyawa kimia yang mempunyai rumus kimia $\mathrm{CaC}_{2}$ bila diberi air akan bereaksi menghasilkan $\mathrm{C}_{2} \mathrm{H}_{2}$ (gas asetilen) dan $\mathrm{Ca}(\mathrm{OH})_{2}$. Gas asetilen inilah yang mempunyai peranan dalam pemeraman buah (Efendi, 2007). Cara atau teknik pemeraman yang tidak tepat dapat menurunkan mutu buah pisang. Sebaliknya, jika proses pemeraman berjalan baik maka akan menghasilkan buah yang seragam kematangannya, dengan rasa yang manis dan mengeluarkan aroma yang harum. Pada proses pematangan buah, terjadi perubahan fisik maupun kimiawi yakni meliputi tekstur, warna dan nilai gizinya. Kandungan gizi pada buah pisang yang masih mentah dan matang tentulah juga pasti berubah. Pada buah pisang banyak kandungan gizi yang menyehatkan. Antara lain karbohidrat, protein, mineral seperti fosfor, magnesium, kalium, dan zat besi, selain itu ada kandungan vitamin juga yakni vitamin A, B dan C. Berdasarkan uraian di atas maka perlu dicari cara dan lama pemeraman buah pisah raja yang menghasilkan buah pisang matang yang bagus dengan kandungan vitamin yang tinggi.

\section{METODE PENELITIAN}

Penelitian dilaksanakan pada bulan Juni sampai bulan September 2012. Peneliti mengambil dua lokasi sebagai tempat pelaksanaan penelitian dikarenakan dalam penelitian ini akan dilaksanakan dalam dua tahap yaitu tahap pemeraman dan tahap pengujian vitamin $\mathrm{C}$. Tahap pemeraman dilaksanakan di desa Muneng Rt 12 Rw 04 kecamatan Pilangkenceng kabupaten Madiun. Tahap pengujian vitamin $\mathrm{C}$ akan dilaksanakan di Laboraturium Biologi IKIP PGRI Madiun. Penelitian ini bersifat eksperimen dengan menggunakan metode Rancangan Acak Lengkap (RAL) disusun secara faktorial dengan 3 kali ulangan. Faktor perlakuan meliputi cara pemeraman dan lama pemeraman. Faktor 1. Cara pemeraman: (a) C1: Cara pemeraman dengan daun lamtoro, (b) C2: Cara pemeraman dengan karbid, (c) C3: Cara pemeraman dengan ethrel. Faktor 2. Lama pemeraman: (a) L0: Lama pemeraman 0 hari, (b) L1: Lama pemeraman 2 hari, (c) L2: Lama pemeraman 4 hari, (d) L3: Lama pemeraman 6 hari.(L4) Lama pemeraman 8 hari. Buah pisang di kelompokkan menjadi 10 kelompok yang salah satunya merupakan kelompok kontrol dan yang sembilan kelompok lainnya merupakan kelompok perlakuan.

Pengambilan sampel dilakukan dengan teknik Sampling acak (Random sampling). Sampel yang diambil secara acak ini bertujuan agar setiap buah pisang sebagai anggota populasi mempunyai peluang yang sama untuk menjadi anggota sampel penelitian. Pengumpulan data dilakukan 
setelah menghitung kadar vitamin $\mathrm{C}$ pada buah pisang raja (Musa paradisiaca $\mathrm{L}$ ) setelah melewati lama pemeraman $0,2,4,6$, dan 8 hari dimana untuk buah pisang 0 hari pemeraman digunakan sebagai kontrol dalam eksperimen ini. Pengumpulan data dilakukan setelah menghitung kadar vitamin $\mathrm{C}$ pada buah pisang raja (Musa paradisiaca L) setelah melewati lama pemeraman $0,2,4,6$, dan 8 hari dimana untuk buah pisang 0 hari pemeraman digunakan sebagai kontrol dalam eksperimen ini.

Instrumen Penelitian: 1. Alat: Alat pemeraman : Tali rafia, Kantong plastik, Rak. Alat pengujian kandungan vitamin $C$ : Blender/juscer, Tabung Erlenmeyer, Kertas saring, Neraca analitik, Buret, Pipet tetes, Gelas Beker. 2. Bahan: Buah pisang raja 51 lirang buah pisang raja, Daun lamtoro $1 \mathrm{~kg} /$ $20 \%$ dari berat pisang yang digunakan, Karbid (Kalsium Karbida) 8gr, Ethepon/ ethrel 1000 ppm 1 liter, Amilum 1\% 30ml, Larutan yodium 0,01 N 300ml, Aquades. Prosedur penelitian meliputi tiga tahap yaitu persiapan, pemeraman, dan pengukuran kadar vitamin $\mathrm{C}$ buah pisang. Analisis data yang digunakan dalam penelitian ini adalah uji varian (ANOVA) ganda menggunakan dua faktor dan tiga kali ulangan. Uji anova ini digunakan karena dalam penelitian ini terdapat dua perlakuan yang ingin diketahui pengaruhnya masing-masing bersama dengan interaksi antara keduanya. Jika dari perhitungan didapat nilai $\mathrm{F}$ hitung $>\mathrm{F}$ tabel maka terdapat nilai signifikan dari perlakuan yang berarti hipotesis diterima. Jika F hitung $<\mathrm{F}$ tabel berarti tidak terdapat pengaruh dari perlakuan dan hipotesis ditolak.

\section{HASIL DAN PEMBAHASAN}

1. Cara Pemeraman Terhadap Kandungan Vitamin C Buah Pisang Raja

Pada pemeraman dengan Ethrel buah pisang mempunyai kandungan vitamin $\mathrm{C}$ yang paling tinggi yakni mencapai $8,51 \mathrm{mg} /$ 100mg. Hal tersebut disebabkan larutan Ethrel mampu membantu buah untuk menghasilkan etilen langsung dari jaringan tanaman itu sendiri (Prabawati et al, 2008:30). Menurut penelitian Suyanti dan Rani (1989) dalam Prabawati et al, (2008:30) bahwa semakin tinggi konsentrasi Ethrel yang digunakan perubahan warna dan pelunakan buah semakin cepat, dan pemacuan tersebut mempercepat penurunan kadar pati diiringi dengan peningkatan kadar gula dan kadar asamnya. Asam-asam organik yang terdapat pada buah-buahan adalah asam sitrat, malat, suksinat dan askorbat. Penggunaan cara pemeraman tanpa menggunakan bahan apa- apa menghasilkan kandungan vitamin $\mathrm{C}$ sebesar 7,81 mg/100mg. Hal tersebut dikarenakan tidak ada etilen yang cukup untuk membantu proses pemasakan buah sehingga kandungan kadar vitamin $\mathrm{C}$ yang dihasilkan cenderung stabil dari awal pemeraman hingga akhir pemeraman. Penggunaan cara pemeraman dengan menggunakan karbid menunjukkan kadar vitamin 7,85mg/100 mg. Karbid (Kalsium Karbida) dapat memicu pembentukan etilen dan karbit juga dapat meningkatkan suhu dalam tempat pemeraman sehingga buah yang diperam dapat mencapai stadium klimaterik lebih cepat namun menurut Muhajir (1989) dalam Prabawati et al, (2008:28) suhu yang terlalu tinggi dapat menyebabkan kelainan fisiologis. Sejalan dengan penelitian Raswen Effendi (2007) bahwa penambahan karbid dalam pemeraman jeruk Siam dapat menurunkan total asam serta meningkatkan total padatan terlarut, sehingga menyebabkan rasa jeruk menjadi manis. Sedangkan menurut hasil penelitian Santosa, Azirifirman dan D. Deswita menyebutkan bahwa dosis pemberian Karbid berpengaruh juga pada mutu dan rasa pada pisang Kepok dan Raja. Pemberian dosis Karbit sebesar 2000 ppm menghasilkan rasa manis yang paling baik untuk pisang Kepok dan Raja Sereh.

Kandungan vitamin $\mathrm{C}$ terkecil didapatkan dari cara pemeraman menggunakan daun yaitu sebesar $7,78 \mathrm{mg} /$ 
100mg. Penggunaan komposisi banyaknya daun yang digunakan dalam pemeraman berpengaruh terhadap kandungan vitamin $\mathrm{C}$ buah pisang, hal tersebut sesuai dengan hasil penelitian Murtiningsih, et al, (1993) dalam Prabawati et al, (2008:30) dan Zahroh (2008) bahwa kenaikan dosis daun akan memicu penurunan kandungan vitamin $\mathrm{C}$ pada buah. Penggunaan $10 \%$ berat daun dari berat buah yang diperam dianggap sudah cukup agar pisang tidak mengalami respirasi yang berlebihan dan mengakibatkan buah cepat rontok dan mengalami susut bobot yang cukup besar (Prabawati et al, 2008:29). Tiap cara pemeraman menghasilkan matang buah yang berbeda- beda. Pemeraman menggunakan bahan kimia cenderung menyebabkan buah pisang cepat rontok dengan warna kulit yang mudah menghitam dan cepat membusuk sehingga tidak dapat disimpan lebih lama.

2. Pengaruh Lama Pemeraman Terhadap Kandungan Vitamin C Buah Pisang Raja

Kandungan vitamin C pada buah pisang dapat dilihat dari gambar 1 berikut ini:

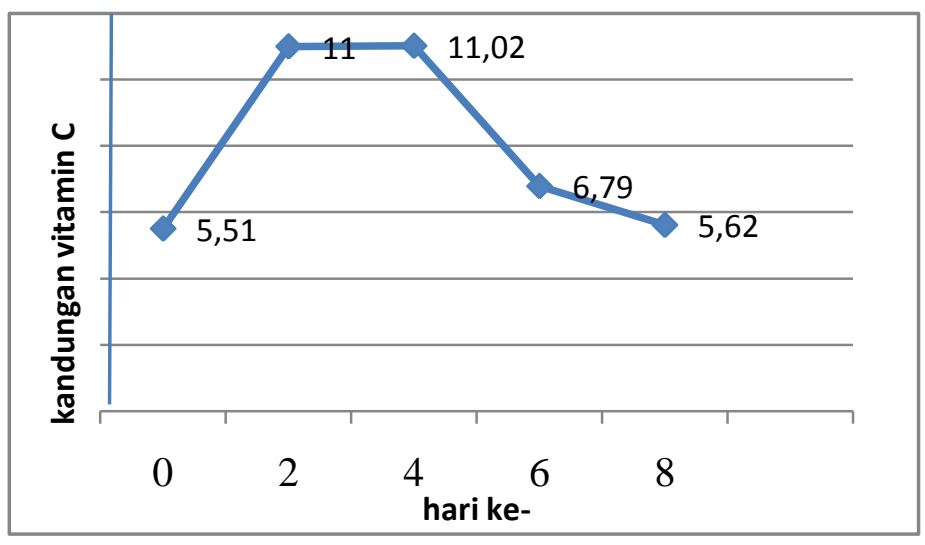

Gambar 1. Grafik Rata-Rata Pengaruh Lama Pemeraman Terhadap Kandungan Vitamin C Buah Pisang Raja

Berdasarkan gambar grafik di atas diketahui bahwa kandungan vitamin $\mathrm{C}$ yang tertinggi terlihat pada hari ke-4 yakni mencapai $11,02 \mathrm{mg} / 100 \mathrm{mg}$ dan kandungan vitamin $\mathrm{C}$ terendah terdapat pada pemeraman hari ke-0. Penurunan vitamin $\mathrm{C}$ disebabkan sifat vitamin $\mathrm{C}$ yang mudah larut dalam air, mempunyai sifat asam serta mudah teroksidasi. Sehingga vitamin $\mathrm{C}$ akan mengalami penurunan apabila kita melakukan penyimpanan dalam waktu lama (Andarwulan dan Koswara, 1992:43) sejalan dengan hasil penelitian Zahroh (2008: 65) yang melakukan penelitian pada pisang Kepok Kuning yang menyatakan semakin lama waktu yang dibutuhkan dalam proses pemeraman maka kadar vitamin $\mathrm{C}$ akan semakin menurun .
Umumnya kandungan asam organik menurun selama pemasakan. Hal ini disebabkan karena asam organik direspirasikan atau diubah menjadi gula. Asam-asam organik dapat dianggap sebagai sumber cadangan energi pada buah, dan kemudian diharapkan menurun selama aktivitas metabolisme selama pemasakan. Perkecualian bagi pisang dan nanas. Pada kedua buah tersebut kandungan asam yang tinggi diperoleh pada stadium masak penuh, namun kandungan asam pada kedua jenis buah ini tidak tinggi saat stadium perkembangan. Fenomena ini bertolak belakang dengan fenomena yang terjadi pada jenis buah lainnya (Santoso, 2005:60).

3. Pengaruh Cara dan Lama Pemeraman Terhadap Kandungan Vitamin C Buah Pisang Raja 
Semua perlakuan yang telah dilakukan pada buah pisang menunjukkan hasil yang signifikan dan terlihat pula perbedaan yang nyata pada sebagian perlakuannya. Kandungan vitamin $\mathrm{C}$ yang didapatkan dari penggabungan dari 2 faktor yakni faktor cara dan lama pemeraman.

Interaksi antara cara dan lama pemeraman terhadap kandungan vitamin $\mathrm{C}$ buah pisang dapat dilihat pada gambar 2 berikut ini:

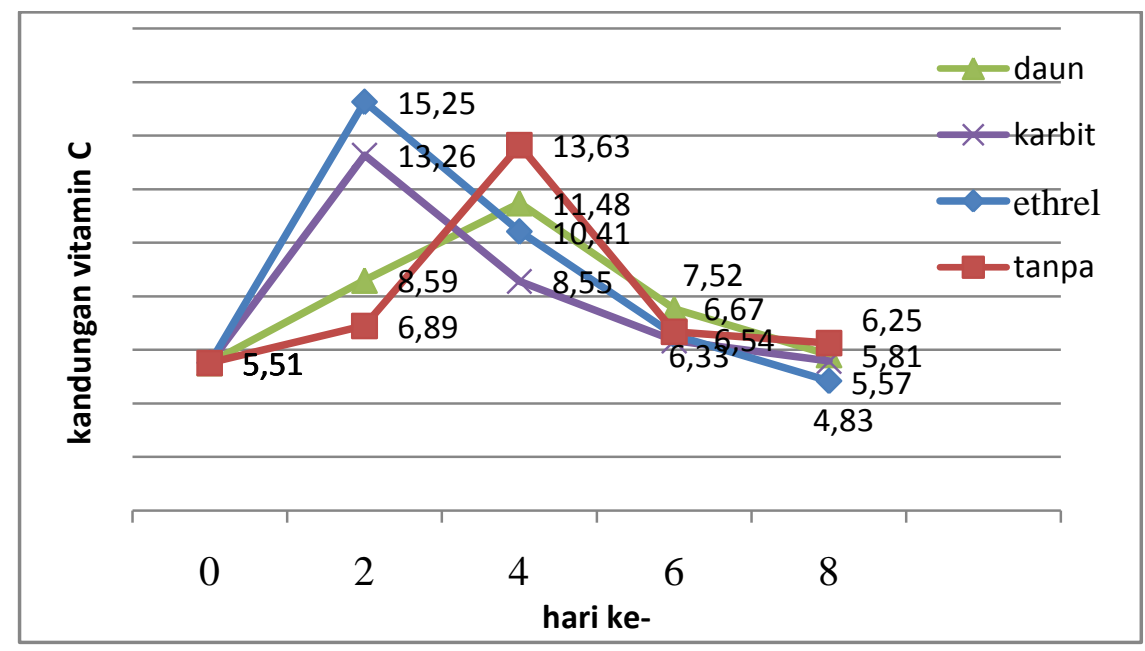

Gambar 2. Grafik Rata-Rata Pengaruh Cara dan Lama Pemeraman Terhadap Kandungan Vitamin C Buah Pisang Raja

Berdasarkan grafik di atas dapat diketahui perbedaan laju kenaikan kandungan vitamin $\mathrm{C}$ buah pisang Raja ketika menuju puncak kematangan (klimaterik) dan penurunan kandungan vitamin $\mathrm{C}$ pada masa pasca klimaterik. Kandungan vitamin $\mathrm{C}$ yang tertinggi didapat dari perlakuan $\mathrm{C} 3 \mathrm{~L} 2$ atau pemeraman Ethrel dengan lama pemeraman 2 hari yaitu sebesar 15,25mg/100mg. Pada pemeraman ethrel dengan lama 2 hari ini pisang Raja mengalami puncak kematangan sehingga kandungan asam askorbat yang terkandung paling tinggi dibandingkan pada hari- hari lainnya, setelah fase klimaterik berakhir kandungan asam askorbat semakin menurun. Pemeraman dengan Ethrel dapat mencapai fase klimaterik lebih awal tetapi juga mengalami pembusukan lebih awal juga, hal tersebut dikarenakan kenaikan tingkat respirasi sehingga dapat mempercepat pematangan namun juga mempercepat pembusukan pada buah.

Pemeraman dengan karbid juga mengalami fase klimaterik pada hari ke 2
(C2L2) dengan kandungan vitamin C sebesar $13,26 \mathrm{mg} / 100 \mathrm{mg}$. Perlakuan cara pmeraman dengan daun Lamtoro dan cara pemeraman tanpa menggunakan bahan apa- apa , fase klimaterik terjadi pada hari ke-4 dan pada hari ke-8 vitamin $\mathrm{C}$ yang terkandung masih relative lebih tinggi dibandingkan semua perlakuan .

\section{KESIMPULAN}

1. Cara pemeraman yang berbeda berpengaruh terhadap kandungan vitamin C buah pisang raja (Musa paradisiaca L). Pemeraman dengan ethrel menghasilkan rata-rata vitamin $\mathrm{C}$ yang paling tinggi yaitu $8,51 \mathrm{mg}$ setiap $100 \mathrm{mg}$ larutan pisang.

2. Lama pemeraman berpengaruh terhadap kandungan vitamin $\mathrm{C}$ pada buah pisang raja (Musa paradisiaca L). Pemeraman pada hari ke-4 menghasilkan vitamin $\mathrm{C}$ paling tinggi untuk semua perlakuan yaitu11,02mg/ 100mg. 
3. Ada interaksi antara cara dan lama pemeraman terhadap kandungan vitamin C buah pisang raja (Musa paradisiaca $\mathrm{L}$ ). Pada cara pemeraman dengan ethrel dan lama pemeraman 2 hari didapatkan kandungan vitamin $\mathrm{C}$ yang berbeda nyata dengan perlakuan yang lain. Kemudian pada cara dan lama pemeraman $4,6,8$ hari ditemukan perbedaan kandungan Vitamin C pula tetapi tidak signifikan.

\section{SARAN}

Perlu dilakukan penelitian ulang untuk uji organolebtik berdasarkan hasil penelitian ini karena dengan uji organoleptik kita akan mengetahui warna, tekstur, rasa, aroma yang paling baik dan paling banyak disukai konsumen, ketahanan pisang.

\section{DAFTAR PUSTAKA}

Arifin. 2009. Pisang. https://arifn. wordpress.com/2009/12/13/pisang/

(Diakses 8 April 2012).

Bambang S Santoso. 2005. Bahan Ajar Pascapanen Hortikultura. http://fp.unram.ac.id/data/DR.Bamb ang\%20B\%20Santoso/BahanAjarPascapanenHortikultura (Diakses tanggal 15 Mei 2012).

Budi Legowo. 2011. Bahan Ajar: Satu Ukuran Profesionalisme Dosen Dalam Proses Pembelajaran. http://legowo.staff.uns.ac.id/2011/0 4/27/bahan-ajar-satu-ukuranprofesionalisme-dosen-dalamproses-pembelajaran/ (Diakses tanggal 10 April 2012.

Departemen Gizi dan Kesehatan Masyarakat. 2011. Gizi dan Kesehatan Masyarakat. Jakarta: Rajawali Grafindo Persada.
Endah Zuhairini. 1997. Budidaya Pisang Raja. Surabaya: Trubus Agrisarana.

Farikhah Asiati Zahroh. 2008. Pengaruh Penggunaan Daun Albasia (Albazzia falcata) dan Lama pemeraman Pisana Kepok Terhadap Kandungan Vitamin $C$. Skripsi tidak diterbitkan. Yogyakarta. Fakultas Sains dan Teknologi Universitas UIN Kalijaga.

Helmiyesi, Rini Budi Hastuti dan Erma Prihastanti. 2008. Pengaruh Lama Penyimpanan Terhadap Kadar Gula dan Vitamin C pada Buah Jeruk Siam (Citrus nobilis var. microcarpa). Buletin Anatomi dan Fisiologi.Volume XVI, Nomor 2, Oktober 2008.

I Wayan Santyasa.2007. Landasan Konseptual Media Pembelajaran. Makalah Workshop Media Pembelajaran bagi Guru-Guru SMA Negeri Banjar Angkan,10 Januari 2007 di Banjar Angkan Klungkung http://downloads. ziddu.com/downloadfile/11250921/ MEDIA_PEMBELAJARAN.zip.ht ml. (Diakses Tanggal 10 April 2012).

Maya Fitriana. 2010. Pengaruh pemberian ethrel dan lama penyimpanan pisang (Musa paradisiaca L) varietas kepok kuning terhadap kandungan vitamin $C$. http://library.um.ac.id/freecontents/i ndex.php/pub/detail/pengaruhpemberian-ethrel-dan-lamapenyimpanan-pisang-musaparadisiaca-l-varietas-kepokkuning-terhadap-kandunganvitamin-c-maya-fitriana-46491.html (Diakses tanggal 10 April 2012). 